\title{
Impact of Fertility Levels and Bio-Fertilizers on Growth, Yield and Economics of Basmati Rice
}

\author{
Abhishek Singh*, U. Sai Sravan, Sandeep Kumar and S.P. Singh \\ Department of Agronomy, Institute of Agricultural Sciences, \\ Banaras Hindu University, Varanasi - 221 005, India \\ *Corresponding author
}

\section{A B S T R A C T}

\begin{tabular}{|l|}
\hline Ke y w or d s \\
BGA, FYM, NPK \\
Levels, PSB, Rice. \\
\hline Article Info \\
\hline Accepted: \\
12 March 2017 \\
Available Online: \\
10 April 2017 \\
\hline
\end{tabular}

A field experiment was conducted at Agricultural Research Farm, Banaras Hindu University, Varanasi, Uttar Pradesh during kharif season, 2015 to evaluate the effect of different NPK levels and bio-fertilizers on growth, yield attributes, yield and economics of basmati rice cv. HUBR 10-9. Factorial experiment was laid out in randomized complete block design involving two factors i.e. four NPK levels (control, 50\% RDF, 75\% RDF and $100 \%$ RDF) and three bio-fertilizer levels (BGA, PSB and BGA + PSB), replicated thrice. Increasing NPK levels up to $100 \%$ RDF improved growth parameters, yield attributes, grain yield, straw yield and net return over the rest of fertility levels. Combined application of BGA + PSB proved significantly superior over alone application of BGA or PSB for the traits studied. However, BGA and PSB were observed at par with each other regarding growth characters, yield attributes and yield. Integration of $100 \%$ RDF along with BGA + PSB performed best in achieving higher growth, productivity and profitability under eastern U.P. conditions.

\section{Introduction}

Rice (Oryza sativa L.) is the prime food crop for more than 65 per cent of the people and provides livelihood security to 70 per cent of Indian population (Kulkarni et al., 2015). Rice occupies 43.9 million hectare with production of 106.5 million tonnes and average productivity of $2424 \mathrm{~kg} \mathrm{ha}{ }^{-1}$ (Anonymous, 2014). With the advent of ever increasing demand, future projections for rice production is to be $170-180$ million tonnes with an average productivity of $4030 \mathrm{~kg} \mathrm{ha}^{-1}$ by the year 2020 (Mishra et al., 2006). As the land area decreasing with time, increasing land use intensity with inadequate and imbalanced use of chemical fertilizers with little or no use of organic manure have caused severe fertility deterioration resulting in stagnating or even declining crop productivity (Shormy et al., 2013). Integrated use of inorganic fertilizers, bio-fertilizers and farmyard manure seem to be the practicable alternative to the present malady of unsustainable agriculture. Farmyard manure is easily available, cheap, proven source of nutrition to agricultural crops and has been used by the farmers traditionally. Besides supplying major and micronutrients it also improves the physical, chemical and biological properties of soil. Use of farmyard manure also augments the response of the bioinoculants, supplies essential nutrients, improves soil health and enhances yield on 
sustained basis (Jobe, 2003). Application of BGA inoculants could be the cheapest and easiest way to increase rice yield because of their capacity to fix atmospheric nitrogen in wetland rice (Begum et al., 1994). Blue green algae has vital role in soil fertility improvement and consequently increasing growth and yield as a natural fertilizer (Song et al., 2005). Phosphate solubilising bacteria (PSB) has the capacity to solubilise and mineralize the residual or fixed phosphorous, increases phosphorus availability in the soil, produces growth substances like indole acetic acid, and gibberellins thus, increases the overall phosphate use efficiency (Chhonkar and Tilak, 1997; Gull et al., 2004). Indian farmers are resource poor and cannot afford chemical fertilizers due to escalating prices. However, it is imperative to use technologies in an integrated manner so that the potential of wetland rice could be realized on sustained basis. The objective of this study was to assess the effect of NPK levels and biofertilizers on growth, yield and economics of basmati rice under wetland condition of eastern Uttar Pradesh.

\section{Materials and Methods}

A field experiment was carried out during kharif season of 2015 at Agricultural Research Farm, Institute of Agricultural Sciences, Banaras Hindu University, Varanasi, Uttar Pradesh to study the effect of NPK levels and bio-fertilizers on growth, yield and economics of basmati rice $\mathrm{cv}$. HUBR 10-9. Treatments consisted of four NPK levels i.e. control, 50\% RDF, 75\% RDF and $100 \%$ RDF and three bio-fertilizers levels viz. BGA, PSB and BGA + PSB with 12 treatment combinations replicated thrice in factorial RCBD. The soil of the experimental field was sandy clay loam in texture, neutral in reaction ( $\mathrm{pH}$ 7.55) (Jackson, 1973), low in organic carbon $(0.38 \%)$ (Walkley and Blak, 1934), medium in available nitrogen (288.17 $\mathrm{kg} \mathrm{ha}^{-1}$ ) (Subbiah and Asija, 1956), low in available $\mathrm{P}_{2} \mathrm{O}_{5}\left(18.40 \mathrm{~kg} \mathrm{ha}^{-1}\right)$ (Olsen et al., 1954) and medium in available $\mathrm{K}_{2} \mathrm{O}(184.40$ $\mathrm{kg} \mathrm{ha}{ }^{-1}$ ) (Jackson, 1973). One third of the recommended dose of nitrogen was applied at planting and the remaining two third was applied in two equal splits at active tillering and panicle initiation stages. Full dose of phosphorus and potassium were applied as basal as per treatments to their respective plots. The sources of fertilizers for NPK were urea $(46 \% \mathrm{~N})$, di-ammonium phosphate $(18 \%$ $\mathrm{N}$ and $\left.46 \% \mathrm{P}_{2} \mathrm{O}_{5}\right)$ and muriate of potash $(60 \%$ $\mathrm{K}_{2} \mathrm{O}$ ). Four week old seedlings of rice were transplanted on the puddled field keeping two seedlings hill $^{-1}$ at a spacing of $20 \mathrm{~cm} \times 15 \mathrm{~cm}$. Recommended dose of fertilizer (RDF) N$\mathrm{P}_{2} \mathrm{O}_{5}-\mathrm{K}_{2} \mathrm{O}$ (120-60-60 $\mathrm{kg} \mathrm{ha}^{-1}$ ) was used for the experimental crop. Well decomposed FYM @ 2 tonnes ha ${ }^{-1}$ applied two days prior to transplanting uniformly to all the treatments. BGA was applied one week after transplanting@10 kg ha ${ }^{-1}$ in the respective treatments. Liquid PSB culture diluted 10 times in distilled water and seedling roots were dipped in solution for about twenty minutes thereafter transplanted immediately to their respective plots. Experimental crop received $871.5 \mathrm{~mm}$ rainfall throughout the crop period, and about $\pm 5 \mathrm{~cm}$ water level was continuously maintained till flowering. Recommended agronomic practices were followed to raise the experimental crop. The data recorded were analyzed following standard statistical analysis of variance procedure as suggested by Gomez and Gomez (1984).

\section{Results and Discussion}

\section{Growth parameters}

In the present investigation, remarkable effect of NPK levels was noticed on growth parameters viz. plant height, number of tillers hill $^{-1}$ and dry matter production hill ${ }^{-1}$ at 
harvest (Table 1). Increasing NPK levels significantly increased plant height and number of tillers hill ${ }^{-1}$ at harvest from control to $100 \% \mathrm{RDF}$ which registered maximum value. However, dry matter production hill ${ }^{-1}$ significantly improved up to $75 \% \mathrm{RDF}$ and further increment in NPK level i.e. 100\% RDF has produced the maximum value but could not produce difference with $75 \%$ RDF. Plants supplied with adequate amount of nutrients $(100 \%$ RDF) produced more leaves and prolific roots which brought about greater accumulation of photosynthates, yielding more plant height, number of tillers hill ${ }^{-1}$ and dry matter production hill ${ }^{-1}$. The results are in conformity with earlier reports (Nanda et al., 2016). Growth parameters viz. plant height, number of tillers hill $^{-1}$ and dry matter production hill $^{-1}$ were significantly affected by bio-fertilizers.
Combined application of BGA + PSB recorded significantly higher growth parameters compared to sole application of BGA and PSB. Blue green algae excrete growth-promoting substances such as hormones (auxin, gibberellin), vitamins, amino acids (Rodriguez et al., 2006). Phosphate solubilizing bacteria (PSB) solubilizes and mineralize the residual or fixed phosphorus, increases the phosphorus availability in soil, produces growth promoting substances and increases the overall phosphate use efficiency (Gull et al., 2004). In present study, the cumulative effect of BGA + PSB was noticeable and this combined application maintained higher availability of nitrogen, phosphorus and other nutrients in soil. The results are in conformity with findings of Meena et al., 2015.

Table.1 Effect of NPK levels and bio-fertilizers on growth characters of basmati rice at harvest stage

\section{Treatments $\quad$ Plant height $(\mathrm{cm}) \quad$ Number of tillers hill $^{-1} \quad$ Dry matter production $\left(\mathrm{g} \mathrm{hill}{ }^{-1}\right)$}

\section{NPK levels (\% RDF)}

\begin{tabular}{lrrr}
0 & 86.20 & 8.28 & 24.11 \\
50 & 95.11 & 9.71 & 28.14 \\
75 & 99.91 & 10.41 & 30.45 \\
100 & 103.35 & 10.93 & 32.03 \\
SEm \pm & 0.79 & 0.15 & 0.58 \\
CD $(P=0.05)$ & 2.33 & 0.43 & 1.70 \\
Bio-fertilizers & & & \\
BGA & 95.33 & 9.32 & 28.10 \\
PSB & 95.47 & 9.67 & 28.17 \\
BGA+PSB & 97.63 & 9.99 & 29.76 \\
SEm \pm & 0.69 & 0.13 & 0.50 \\
CD $(P=0.05)$ & 2.02 & 0.38 & 1.48 \\
\hline
\end{tabular}


Table.2 Effect of NPK levels and bio-fertilizers on yield attributes and yield of basmati rice

\begin{tabular}{|c|c|c|c|c|c|}
\hline Treatments & $\begin{array}{l}\text { Filled grains } \\
\text { panicle }^{-1}\end{array}$ & $\begin{array}{l}\text { Unfilled grains } \\
\text { panicle }^{-1}\end{array}$ & $\begin{array}{l}\text { 1000-grain } \\
\text { weight (g) }\end{array}$ & $\begin{array}{l}\text { Grain yield } \\
\left(q h^{-1}\right)\end{array}$ & $\begin{array}{l}\text { Straw yield } \\
\left.(\mathbf{q ~ h a})^{-1}\right)\end{array}$ \\
\hline \multicolumn{6}{|c|}{ NPK levels (\% RDF) } \\
\hline 0 & 98.88 & 32.95 & 19.98 & 36.90 & 54.36 \\
\hline 50 & 121.98 & 25.78 & 21.58 & 47.85 & 70.48 \\
\hline 75 & 133.60 & 23.23 & 22.46 & 53.03 & 78.13 \\
\hline 100 & 142.89 & 21.44 & 22.97 & 57.16 & 84.18 \\
\hline $\mathrm{SEm} \pm$ & 2.82 & 0.65 & 0.19 & 0.90 & 1.33 \\
\hline $\mathrm{CD}(P=0.05)$ & 8.29 & 1.90 & 0.56 & 2.65 & 3.91 \\
\hline \multicolumn{6}{|c|}{ Bio-fertilizers } \\
\hline BGA & 120.86 & 26.63 & 21.52 & 47.57 & 70.02 \\
\hline PSB & 122.12 & 26.44 & 21.57 & 48.09 & 70.91 \\
\hline $\mathrm{BGA}+\mathrm{PSB}$ & 130.03 & 24.48 & 22.12 & 50.55 & 74.43 \\
\hline $\mathrm{SEm} \pm$ & 2.44 & 0.56 & 0.16 & 0.78 & 1.16 \\
\hline $\mathrm{CD}(P=0.05)$ & 7.18 & 1.64 & 0.48 & 2.29 & 3.39 \\
\hline
\end{tabular}

Table.3 Effect of NPK levels and bio-fertilizers on the economics of basmati rice

\begin{tabular}{|c|c|c|c|c|}
\hline Treatments & $\begin{array}{c}\text { Cost of cultivation } \\
\left(₹ \mathbf{h a}^{-1}\right)\end{array}$ & $\begin{array}{l}\text { Gross return } \\
\left(₹ \text { ha }^{-1}\right)\end{array}$ & $\begin{array}{l}\text { Net return } \\
\left(₹ \text { ha }^{-1}\right)\end{array}$ & B:C ratio \\
\hline \multicolumn{5}{|c|}{ NPK levels (\% RDF) } \\
\hline 0 & 29277.51 & 67139.07 & 37861.38 & 1.30 \\
\hline 50 & 32900.03 & 87037.86 & 54137.28 & 1.64 \\
\hline 75 & 34471.75 & 96462.28 & 61990.53 & 1.80 \\
\hline 100 & 36043.17 & 103969.80 & 67926.40 & 1.88 \\
\hline SEm \pm & - & 1639.46 & 1400.73 & 0.04 \\
\hline $\mathrm{CD}(P=0.05)$ & - & 4808.68 & 4108.45 & 0.10 \\
\hline \multicolumn{5}{|c|}{ Bio-fertilizers } \\
\hline BGA & 33013.12 & 86489.81 & 53476.29 & 1.60 \\
\hline PSB & 32973.12 & 87450.02 & 54460.12 & 1.63 \\
\hline $\mathrm{BGA}+\mathrm{PSB}$ & 33533.12 & 92016.89 & 58500.29 & 1.74 \\
\hline $\mathrm{SEm} \pm$ & - & 1419.82 & 1213.07 & 0.03 \\
\hline $\mathrm{CD}(P=0.05)$ & - & 4164.44 & 3558.03 & 0.09 \\
\hline
\end{tabular}

\section{Yield attributes and yield}

The NPK levels exerted significant effect on number of filled grains panicle ${ }^{-1}$, number of unfilled grains panicle ${ }^{-1}$, 1000-grain weight, grain and straw yields of rice (Table 2). The maximum number of filled grains panicles $^{-1}$, minimum number of unfilled grains panicles ${ }^{1}$, maximum 1000-grain weight, grain and straw yields were recorded with $100 \%$ RDF where increasing NPK levels significantly increased the above traits and grain yield up to $100 \%$ RDF. NPK levels tried in the study differed significantly among themselves for all yield attributes except for 1000-grain weight and number of unfilled grain panicle ${ }^{-1}$ where $100 \% \mathrm{RDF}$ and $75 \%$ RDF could not produce the difference. Continuous supply of 
nutrients in balanced quantity throughout the growth stages assisted the plants to assimilate adequate photosynthates and their effective translocation to reproductive parts increased the yield attributes and yield of rice. These findings are in close agreement with reports of (Patel et al., 2015; Nanda et al., 2016). Application of bio-fertilizers had noticeable influence on filled grains panicle ${ }^{-1}$, unfilled grains panicle ${ }^{-1}$, 1000-grain weight, grain and straw yields of rice. The 1000-grain weight, grain and straw yield registered their maximum values with combined application of BGA + PSB which was significantly higher than application of BGA and PSB alone. Addition of BGA along with PSB significantly increased the yield attributes, grain and straw yield than sole application of PSB. Conversion of insoluble phosphorus to soluble form due to acidification, chelation and several other mechanisms coupled with additional $\mathrm{N}$ released after mineralization of dead algal cells and increased phosphorus availability in soil led to better matching between nutrient demand by crop and its supply by soil. So, higher dry matter accumulation and translocation to reproductive pats hence had a favorable effect on yield attributes and yield of rice. These results are in close conformity with the earlier findings (Meena et al., 2014; Patel et al., 2015)

\section{Economics}

Economics (cost of cultivation, gross return, net return and $\mathrm{B}$ : $\mathrm{C}$ ratio) was influenced due to different NPK levels and bio-fertilizers (Table 3). Among the NPK levels Maximum gross return (₹103969.80 $\mathrm{ha}^{-1}$ ) and net return (₹ $67926.40 \mathrm{ha}^{-1}$ ) recorded with $100 \% \mathrm{RDF}$ which was significantly superior over all the NPK levels and maximum B: $C$ ratio (1.88) was recorded with $100 \%$ RDF which was significantly at par with $75 \%$ RDF. These results are in close conformity with the findings of Singh et al., 2014. Among the biofertilizers tested, application of BGA + PSB recorded maximum gross return, net return and benefit: cost ratio. Maximum gross return (₹ $92016.89 \mathrm{ha}^{-1}$ ), net return (₹ $58500.29 \mathrm{ha}^{-1}$ ) and B: C ratio (1.74) was recorded with combined application of BGA + PSB which was found significantly better than sole application of BGA and PSB. This finding has been closely confirmed by (Nanda et al., 2016).

On the basis of above findings it may be concluded that integration of highest NPK level (100\% RDF) along with combined application of BGA and PSB proved better for achieving higher productivity and net return of basmati rice cv. HUBR 10-9 for Varanasi region.

\section{References}

Anonymous. 2014. Agricultural Statistics at a Glance. Directorate of Economics and Statistics, Department of Agriculture and Cooperation, Ministry of Agriculture, Government of India, New Delhi, pp. 6163.

Begum, Z.N.T., Mandal, R., Khan, Z.U.M. and Hossain, M.Z. 1994. Prospect and potentiality of cyanobacteria as an alternative source of nitrogen fertilizer in Bangladesh rice cultivation. In: Biological nitrogen fixation associated with rice production, pp. 119-132.

Chhonkar, P.K., and Tilak, K.V.B.R. 1997. Biofertilizers for sustainable agriculture: Research gaps and future needs. In:Plant Nutrient Needs Supply, Efficiency and Policy Issues: 2000-2025 (Eds. J.S. Kanwar and J.C. Katyal). National Academy of Agricultural Sciences, New Delhi. pp. 52-66.

Gomez, K.A. and Gomez, A.A. 1984. Statistical procedures for agricultural research, Second edition, J. and Wiley Sons, New York. pp. 91-97.

Gull, M., Hafeez, F.Y., Saleem, M. and Malik, 
K.A. 2004. Phosphorus uptake and growth promotion of rice by co inoculation of mineral phosphate solubilizing bacteria and mixed rhizobial culture. Aust. J. Experim. Agric., 44: 623628.

Jackson, M.L. 1973. Soil Chemical Analysis, Prentice Hall of India Pvt. Ltd., New Delhi. pp. 183-204.

Jobe. 2003. Integrated nutrient management for increased rice production in the inland valleys of the Gambia. In:Sanyang S., A. Ajayi and A.A. Sy (eds). Proceedings of the Second Biennial Regional Rice Research Review. WARDA Proceedings Series no. 2, Vol 1. pp. 35-41.

Kulkarni, M.V., Patel, A.M. and Pawar, Y. 2015. Influence of INM on soil physical parameters and yield of transplanted and drilled rice. The Ecoscan, 9: 377-379.

Meena, R.K., Nanda, G., Neupane, M.P. and Singh, S.P. 2015. Effect of Phosphorus Levels and Bio-Organic Sources on Growth attributes and Yield of Rice. The Ecoscan, 9: 579-582.

Mishra, D., Ispalasmed, M., Rao, K.V. and Bentor, J.S. 2006. Rice research in India: Green revolution to gene revolution. $J$. Rice Res., 1: 35-38.

Nanda, G., Sravan, U.S., Singh, A. and Singh, S.P. 2016. Effect of NPK Levels and BioOrganics on Growth, Yield and Economics of Basmati Rice (Oryza sativa L.) cv. HUBR 10-9. Environ. Ecol., 34: 1530-1534.

Olsen, S.R., Cole, C.V., Walanabe, F.S. and Dean, L.A. 1954. Estimation of available phosphorus in soil by extraction with sodium bicarbonate. United States
Department of Agriculture, Circular, 939: pp. 19-23.

Patel, A., Neupane, M.P., Nanda, G. and Singh, S.P. 2015. Effect of NPK Management and Bio-inoculants on Growth and Yield of wetland Rice. Environ. Ecol., 34: 181185.

Rodriguez, A.A., Stella, A.A., Storni, M.M., Zulpa, G. and Zaccaro, M.C. 2006. Effects of cyanobacterial extra celular products and gibberellic acid on salinity tolerance in Oryza sativa L. Saline System, 2: 7.

Shormy, S.A.S., Chowdhury, M.A.H., Saha, B.K. and Haque, M.A. 2013. Effects of different sources of organic materials on nutrient contents and their uptake by $\mathrm{T}$. aman rice. J. Agron. Environ., 7: 37-40.

Singh, S., Singh, S.P., Neupane, M.P. and Meena, R.K. 2014. Effect of NPK levels, BGA and FYM on growth and yield of rice (Oryza sativa L.). Environ. Ecol., 32: 301-303.

Song, T., Martensson, L., Eriksson, T., Zheng, W. and Rasmussen, U. 2005. Biodiversity and seasonal variation of the cyanobacterial assemblage in a rice paddy field in Fujian, China. The Federation of European Materials Soc. Microbiol. Ecol., 54: 131-140.

Subbiah, B.V. and Asija, G.L. 1956. A rapid procedure for estimation of available nitrogen in soils. Curr. Sci. 25, 259-260.

Walkley, A.J., and Black, I.A. 1934. An examination of the Degtjareef method for determining soil organic matter and a proposed modification of the chromic acid titration method. Soil Sci., 34: 29-38.

\section{How to cite this article:}

Abhishek Singh, U. Sai Sravan, Sandeep Kumar and Singh, S.P. 2017. Impact of Fertility Levels and Bio-Fertilizers on Growth, Yield and Economics of Basmati Rice. Int.J.Curr.Microbiol.App.Sci. 6(4): 1471-1476. doi: https://doi.org/10.20546/ijcmas.2017.604.179 